\title{
OPTIMALISASI SUBSTITUSI TEPUNG AZOLLA TERFERMENTASI PADA PAKAN IKAN UNTUK MENINGKATKAN PRODUKTIVITAS IKAN NILA GIFT
}

\author{
HANY HANDAJANI \\ Jurusan Perikanan Universitas Muhammadiyah Malang \\ E-mail: handajani@umm.ac.id
}

\begin{abstract}
ABSTRAK
Penelitian ini dilakukan untuk mengetahui substitusi tepung Azolla fermentasi yang mengoptimalkan tingkat pertumbuhan dan daya cerna di Tilapia. Penelitian ini berdasarkan Rancangan Acak Lengkap (RAL) dengan tiga ulangan . Empat tingkat penggunaan bungkil kedelai dengan tepung Azolla difermentasi adalah: P0 (100\%:0\%), P1 (85\%:15\%), P2 (70\%:30\%), dan P3 (55\%:45\%). Parameter utama adalah tingkat pertumbuhan mutlak, konversi pakan, dan daya cerna Tilapia (Oreochiomis sp.). Hasil penelitian menunjukkan bahwa penggunaan bungkil kedelai dengan tepung Azolla fermentasi berpengaruh signifikan pada tingkat pertumbuhan dan parameter daya cerna. Perlakuan P1 memberikan hasil terbaik dengan pertumbuhan mutlak 0,81 gram menilai, konversi pakan 3,14 dan kecernaan 67,68\%.
\end{abstract}

Kata kunci: pakan ikan, tepung azolla tefermentasi, tilapia

\begin{abstract}
The research has been conducted to evaluate the fermented Azolla flour substitutions that optimize the growth rate and digestibility in Tilapia. The research was based on Completely Randomized Design (CRD) with three replications. Four levels of substitution of soy meal with fermented Azolla flour were: P0 (100\%:0\%), P1 (85\%:15\%), P2 (70\%:30\%), and P3 (55\%:45\%). The main parameters were absolute growth rate, feed conversion, and digestibility of Tilapia (Oreochiomis sp.). The result showed that the substitution of soy meal with fermented Azolla flour has significant effect in growth rate and digestibility parameters. The P1 treatment gave the best result with growth absolute rate of 0.81 gram, feed conversion of 3.14 and $67.68 \%$ digestibility.
\end{abstract}

Key words: fish feed, fermented azolla flour, tilapia

\section{PENDAHULUAN}

Usaha budidaya ikan sangat dipengaruhi oleh ketersediaan pakan yang cukup dalam jumlah dan kualitasnya untuk mendukung kualitas yang maksimal. Faktor pakan menentukan biaya produksi mencapai 60-70\% dalam usaha budidaya ikan sehingga perlu pengelolaan yang efektif dan efisien. Beberapa syarat bahan pakan yang baik untuk diberikan adalah memenuhi kandungan gizi (protein, lemak, karbohidrat, vitamin dan mineral) yang tinggi, tidak beracun, mudah diperoleh, mudah diolah dan bukan sebagai makanan pokok manusia. Sampai saat ini sumber protein nabati yang digunakan dalam pakan ikan adalah tepung kedelai. Harga kedelai terus meningkat dan saat ini mencapai Rp. 4500/kg. Ada beberapa alternatif bahan pakan yang dapat dimanfaatkan dalam penyusunan pakan salah satunya adalah tepung Azolla. Tanaman Azolla merupakan gulma air yang tidak termanfaatkan, tetapi memiliki kandungan protein yang cukup tinggi, yaitu 28,12\% berat kering (Handajani, 2000), sedangkan Lumpkin dan Plucknet (1982) menyatakan kandungan protein pada Azolla sp. sebesar 23,42\% berat kering dengan komposisi asam amino esensial yang lengkap. Karenanya, tanaman Azolla sangat berpotensi sebagai bahan penyusun pakan ikan sebagai sumber protein nabati pengganti tepung kedelai.

Hasil penelitian Handajani (2006) menyatakan kandungan serat kasar tepung Azolla sebesar 23,06\%. Tepung Azolla dimanfaatkan sebagai salah satu penyusun pakan ikan Nila Gift dengan hasil daya cerna protein ikan berkisar 55,51-67,68\%. Di samping itu dari hasil penelitian Haetami dan Sastrawibawa (2005) nilai daya cerna ikan Gurami terhadap pakan yang menggunakan tepung Azolla berkisar 58,70-67,90\%. Nilai daya cerna ini belum maksimal karena pakan yang diberikan tidak tercerna dengan baik. Hal ini disebabkan kandungan serat kasar yang cukup tinggi pada tepung Azolla. Selanjutnya 
Handajani (2007) mencoba meningkatkan nilai gizi tepung azolla melalui proses fermentasi dan didapatkan hasil fermentasi tepung azolla dengan Rhizophus $s p$ memberikan hasil yang terbaik dari beberapa fermentor, terbukti dapat menurunkan kandungan serat kasar tepung Azolla dari 23,06\% menjadi $14,62 \%$.

Dari beberapa hasil penelitian tersebut perlu dilakukan pengujian untuk memanfaatkan tepung Azolla terfermentasi dalam pakan ikan Nila Gift. Hasil penelitian diharapkan tepung Azolla terfermentasi dapat mensubstitusi tepung kedelai dalam penyusunan pakan ikan. Hal tersebut diharapkan dapat meningkatkan produksi ikan Nila serta menekan biaya produksi karena tepung Azolla terfermentasi yang digunakan sebagai substitusi tepung kedelai mempunyai nilai ekonomis yang rendah sebesar Rp1000/kg.

\section{METODE}

Materi yang digunakan adalah ikan uji berupa benih ikan Nila yang berukuran 5-7 cm dengan berat rata-rata 1,3 gram. Media percobaan yang digunakan berupa air tawar yang berasal dari air sumur. Air ditempatkan pada akuarium percobaan yang berjumlah 16 buah dengan volume masingmasing 20 liter. Kualitas air diusahakan optimal bagi pertumbuhan ikan uji.
Pada penelitian ini akan digunakan empat macam pakan percobaan dengan kandungan protein 25\% dengan energi $360 \mathrm{kkal} / \mathrm{g}$ pakan. Protein terdiri dari tepung ikan sebagai protein hewani dan tepung Azolla sebagai bahan substitusi protein tepung kedelai untuk protein nabati. Alatalat penelitian yang digunakan dalam penelitian ini adalah akuarium, aerator, selang, serok, batu aerasi, blender, timbangan, tissue, pipet ukur, thermometer, peralatan analisis proksimat, dan peralatan kualitas air.

Bahan-bahan pakan yang akan digunakan sebagai penyusun pakan dianalisis proksimat, komposisi nutrisi bahan pakan dapat dilihat pada Tabel 1. Metode penelitian yang digunakan adalah metode eksperimen. Penelitian ini menggunakan Rancangan Acak Lengkap (RAL). Perlakuan ditentukan/didapatkan dari hasil penyusunan

Tabel 3. Hasil Proksimat Pakan Uji

\begin{tabular}{lcccr}
\hline \multicolumn{1}{c}{ Kandungan } & P0 & P1 & P2 & \multicolumn{1}{c}{ P3 } \\
\hline Berat kering (\%) & 88,57 & 89,15 & 88,04 & 87,47 \\
Protein (\%) & 24,52 & 24,75 & 24,94 & 24,66 \\
Lemak (\%) & 9,38 & 7,5 & 6,65 & 7,80 \\
Serat kasar (\%) & 4,53 & 6,24 & 9,045 & 13,58 \\
Abu (\%) & 13,24 & 14,23 & 12,76 & 16,72 \\
BETN & 36.9 & 36,43 & 34,65 & 24,71 \\
\hline
\end{tabular}

Tabel 1. Komposisi nutrisi bahan pakan ikan Nila Gift (Oreochromis, sp)

\begin{tabular}{|c|c|c|c|c|c|c|}
\hline Bahan & Protein $(\%)$ & Lemak (\%) & Serat Kasar (\%) & Abu (\%) & BETN & DE (kkal/g) \\
\hline Tepung ikan & 50,07 & 4,9 & 8,68 & 26,93 & 9,42 & 282,06 \\
\hline Tepung kedelai & 37,58 & 18,28 & 9,56 & 4,43 & 30,15 & 435,44 \\
\hline Tepung Azolla & 19,54 & 8,8 & 23,06 & 12,48 & 36,12 & 307,28 \\
\hline Tepung Azolla Fermentasi & 20.05 & 6,42 & 14,62 & 12,83 & 37,05 & 368.27 \\
\hline Bekatul & 10,79 & 10,56 & 12,86 & & & 411.24 \\
\hline Tepung tapioka & 3,34 & 0,55 & 0,53 & 0,58 & 95,00 & 398,31 \\
\hline
\end{tabular}

(Hasil analisis laboratorium Nutrisi Fapetrik 2008 - UMM)

Tabel 2. Formulasi Pakan ikan Nila Gift

\begin{tabular}{|c|c|c|c|c|}
\hline \multirow{2}{*}{ Bahan } & \multicolumn{4}{|c|}{ Perbandingan Tepung Kedelai dengan Tepung Azolla Fermentasi } \\
\hline & P0 = 100: 0 & P1 = 85: 15 & P2 = 70: 30 & P3 = 55: 45 \\
\hline Tepung ikan & 22,5 & 22,5 & 22,5 & 22,5 \\
\hline Tepung kedelai & 29,5 & 25,07 & 20,65 & 16,22 \\
\hline Bekatul & 22,75 & 22,75 & 18,5 & 18,5 \\
\hline Tepung Tapioka & 19,25 & 19,25 & 13,5 & 13,5 \\
\hline Tepung Azolla Fermentasi & 0 & 4,43 & 8,85 & 13,27 \\
\hline Minyak kelapa & 0 & 0 & 0,58 & 0,61 \\
\hline Mineral Mix & 2 & 2 & 2 & 2 \\
\hline Vitamin Mix & 2 & 2 & 2 & 2 \\
\hline $\mathrm{Cr}_{2} \mathrm{O}_{3}$ & 0,5 & 0,5 & 0,5 & 0,5 \\
\hline Jumlah & 100 & 100 & 100 & 100 \\
\hline Protein (\%) & 27,83 & 24,96 & 23,62 & 22,93 \\
\hline Energi (kkal/g) & 417,59 & $\mathbf{3 7 6 , 5 7}$ & 381,41 & 379,28 \\
\hline
\end{tabular}


formulasi pakan, masing-masing perlakuan diulang sebanyak 3 kali.

Variabel uji yang diamati adalah pertumbuhan mutlak (Effendi, 1997), daya cerna protein (D) metode Chromix Oxide (Zonneveld, 1991), dan rasio konversi pakan (Zonneveld, 1991). Data yang diperoleh dianalisis dengan menggunakan sidik ragam (anova). Apabila hasil analisis menunjukkan perbedaan akan dilanjutkan dengan Uji Beda Nyata Terkecil (BNT).

\section{HASIL DAN PEMBAHASAN}

\section{Pertumbuhan}

Pola pertumbuhan ikan nila gift (Oreochiomis $s p$.) adalah eksponensial. Dengan menggunakan pola ini, maka diperoleh data pertumbuhan mutlak untuk tiap-tiap perlakuan seperti tertera pada Gambar 1.

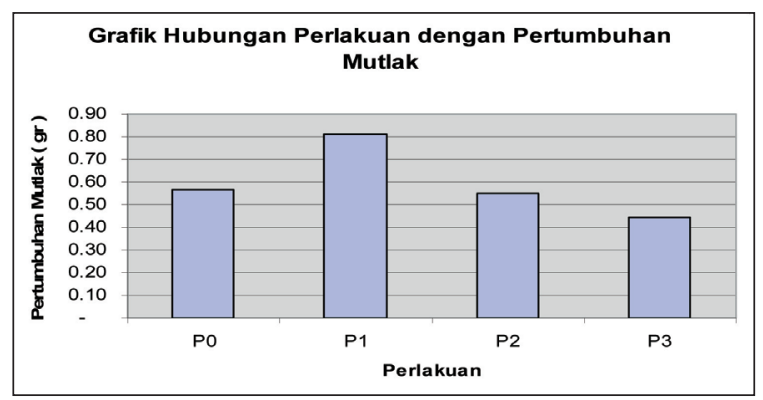

Gambar 1. Grafik rata-rata pertumbuhan mutlak ikan nila gift tiap-tiap perlakuan selama penelitian.

Keterangan:

P0 = tepung Azolla terfermentasi 0\% tepung kedelai $100 \%$

P1 $=$ tepung Azolla terfermentasi 15\% tepung kedelai $85 \%$

P2 = tepung Azolla terfermentasi 30\% tepung kedelai $70 \%$

P3 $=$ tepung Azolla terfermentasi 45\% tepung kedelai $55 \%$

Hasil perhitungan sidik ragam menunjukkan bahwa, perlakuan pemanfaatan tepung Azolla terfermentasi sebagai substitusi protein tepung kedelai dalam ransum memberikan pengaruh yang berbeda terhadap pertumbuhan mutlak pada ikan nila gift (Oreochiomis sp.).

Hasil penelitian menunjukkan adanya perbedaan pada substitusi tepung Azolla terfermentasi terhadap tepung kedelai. Hal ini menunjukkan bahwa penggunaan tepung Azolla terfermentasi dapat digunakan sebagai substitusi tepung kedelai sebesar 15\%. Hasil subtitusi tepung Azolla terfermentasi sebesar $15 \%$ dengan tepung kedelai 85\%, menghasilkan pertumbuhan mutlak lebih tinggi $(0,81)$ dibandingkan dengan pakan yang mengandung tepung kedelai $100 \%(0,57)$. Hal ini disebabkan oleh kandungan asam-asam amino dari subtitusi tepung Azolla terfermentasi (15\%) dan tepung kedelai (85\%) lebih tinggi dibandingkan pada pakan yang $100 \%$ tepung kedelai. Karenanya apabila pakan yang diberikan mempunyai nilai nutrisi yang baik, maka dapat mempercepat laju pertumbuhan karena zat tersebut akan dipergunakan untuk menghasilkan energi mengganti sel-sel tubuh yang rusak. Zat-zat nutrisi yang dibutuhkan adalah protein, lemak, karbohidrat, vitamin, mineral (Handajani dan Widodo, 2010).

Pada penelitian ini jumlah pakan yang diberikan disesuaikan dengan kebutuhan ikan yaitu 5 persen dari berat tubuh ikan per hari. Di samping itu komposisi pakan yang diberikan terutama pada kandungan protein sudah berada pada kisaran optimum yaitu sebesar \pm 25 persen. Hal ini sesuai dengan hasil penelitian Ahmad dan Tawwab (2010), bahwa umumnya ikan membutuhkan pakan yang kandungan proteinnya 20-60 persen sedangkan optimumnya adalah berkisar antara 30-60 persen.

Dari data tersebut diketahui bahwa perlakuan yang memberikan laju pertumbuhan mutlak tertinggi dicapai pada pakan dengan tingkat substitusi $15 \%$ sebesar 0,81. Kemudian pakan dengan tingkat substitusi $0 \%$ memiliki rata-rata pertumbuhan mutlak sebesar 0,57 . Selanjutnya pakan dengan tingkat substitusi 30\% memiliki rata-rata pertumbuhan mutlak sebesar 0,55. Pakan dengan tingkat substitusi $45 \%$ memiliki rata-rata pertumbuhan mutlak sebesar 0,44. Maka, syarat utama yang harus diperhatikan dalam pembuatan pakan ikan antara lain: kandungan nutrisi suatu bahan pakan harus cukup sesuai dengan kebutuhan ikan, disukai oleh ikan, mudah dicerna dan jika dilihat dari nilai ekonominya pakan yang dihasilkan dari pemanfaatan tepung Azolla mempunyai harga yang relatif lebih murah jika dibanding dengan penggunaan tepung kedelai sehingga dengan pemanfaatan tepung Azolla dapat menekan biaya produksi pakan.

\section{Rasio Konversi Pakan (Feed Convertion Ratio)}

Rasio konversi pakan merupakan salah satu parameter efisiensi pemberian pakan. Data perhitungan rasio konversi pakan pada ikan nila gift (Oreochiomis sp.) untuk tiap-tiap perlakuan selama penelitian disajikan pada Gambar 2. Hasil perhitungan sidik ragam menunjukkan bahwa perlakuan pemanfaatan tepung Azolla terfermentasi sebagai substitusi protein tepung kedelai dalam ransum memberikan pengaruh yang berbeda terhadap rasio konversi pakan pada ikan nila gift (Oreochiomis sp.). 


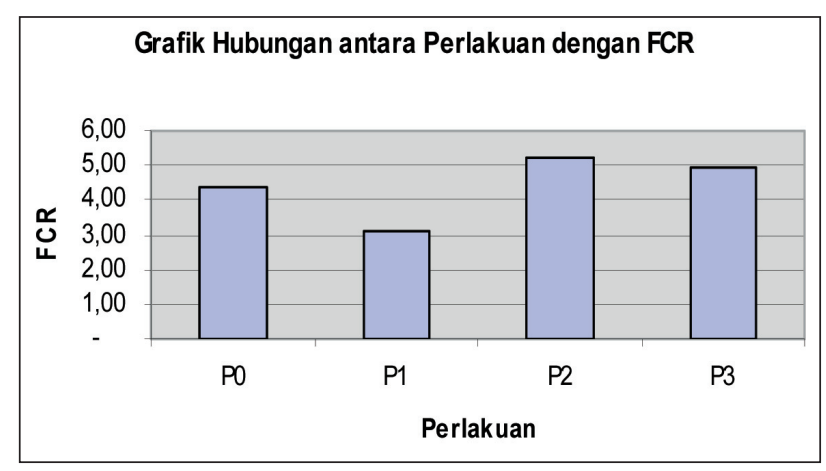

Gambar 2. Grafik Rata-rata Rasio Konversi Pakan (FCR) Ikan Nila Gift (Oreochiomis sp.) Tiaptiap Perlakuan Selama Penelitian.

Tingkat efisiensi penggunaan pakan pada ikan nila gift (Oreochiomis sp.) ditentukan oleh pertumbuhan dan jumlah pakan yang diberikan. Keefisienan penggunaan pakan menunjukkan nilai pakan yang dapat merubah menjadi pertambahan pada berat badan ikan (Uktolseja, 2008). Efisiensi pakan dapat dilihat dari beberapa faktor dimana salah satunya adalah rasio konversi pakan. Nilai rasio konversi pakan pada penelitian ini berdasarkan perhitungan statistik menunjukkan bahwa pemanfaatan tepung Azolla sebagai bahan substitusi protein tepung kedelai dalam ransum berpengaruh nyata terhadap rasio konversi pakan. Hal ini dipengaruhi oleh pertumbuhan dan nilai kualitas dan kuantitas pakan yang diberikan, selanjutnya juga dipengaruhi oleh adanya tingkat konversi pakan dengan bertambahnya berat badan ikan sehingga semakin tinggi berat badan ikan maka semakin tinggi pula konversi pakan yang dimanfaatkan. Menurut Hariati (1989) bahwa tingkat efisiensi penggunaan pakan yang terbaik akan dicapai pada nilai perhitungan konversi pakan terendah, dimana pada perlakuan tersebut kondisi kualitas pakan lebih baik dari perlakuan yang lain. Kondisi kualitas pakan yang baik mengakibatkan energi yang diperoleh pada ikan nila gift (Oreochiomis sp.) lebih banyak untuk pertumbuhan, sehingga ikan nila gift (Oreochiomis sp.) dengan pemberian pakan yang sedikit diharapkan laju pertumbuhan meningkat.

\section{Daya Cerna Ikan Nila GIFT (Oreochiomis sp.)}

Daya cerna adalah kemampuan untuk mencerna suatu bahan, sedangkan bahan yang tercerna adalah bagian dari pakan yang tidak diekskresikan dalam feses. Nilai nutrisi dari suatu makanan bagi ikan bergantung pada sejauh mana ikan tersebut mampu mencerna makanan tersebut. Untuk mengetahui besarnya daya cerna ikan terhadap makanan dapat dilakukan dengan menggunakan Chromix Oxide
$\left(\mathrm{Cr}_{2} \mathrm{O}_{3}\right)$ sebagai indikator. Selanjutnya feses yang mengandung $\mathrm{Cr}_{2} \mathrm{O}_{3}$ dikumpulkan dan dianalisis kandungan zat tersebut. Perbandingan $\mathrm{Cr}_{2} \mathrm{O}_{3}$ dalam pakan dan feses dapat memberikan perkiraan daya cerna pakan (Tilman, et al., 1996). Dari hasil penelitian didapatkan data daya cerna protein yang disajikan pada Gambar 3. Daya cerna protein yang tinggi menunjukkan bahwa pakan tersebut baik dan nutrien pakan dapat dimanfaatkan secara efisien oleh ikan nila GIFT (Oreochiomis sp.) untuk menyusun produksi tubuhnya.

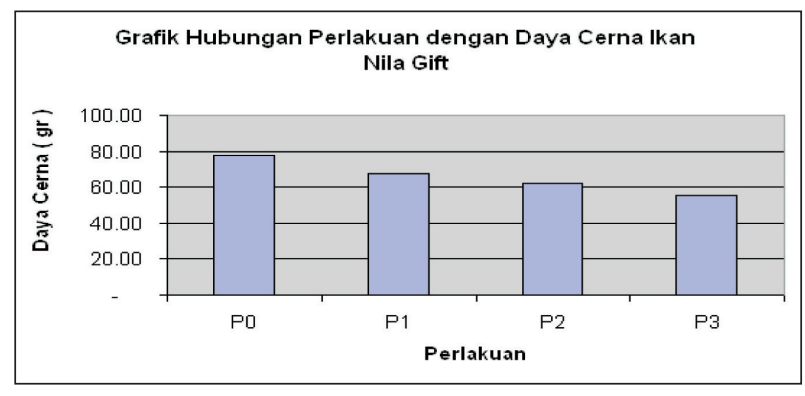

Gambar 3. Grafik Daya Cerna Pada Ikan Nila GIFT (Oreochiomis sp.) Tiap-tiap Perlakuan Selama Penelitian.

Dari Gambar 3 di atas dapat diketahui bahwa nilai daya cerna portein merupakan hal yang sangat penting untuk mengetahui efesiensi pakan yang diberikan pada ikan. Pada Gambar 3 dapat dilihat perlakuan P0 (0\% tepung Azolla terfermentasi) daya cernanya 77,50\%, kemudian diikuti perlakuan P1 (15\% tepung Azolla terfermentasi) daya cernanya $67,68 \%$, P2 (30\% tepung Azolla terfermentasi) daya cernanya 62,19\% dan P3 (45\% tepung Azolla terfermentasi) daya cernanya $55,51 \%$. Hal ini disebabkan karena protein dalam pakan telah dipecah menjadi asamasam amino yang lebih mudah diserap oleh ikan dan kebutuhan nutriennya sudah terpenuhi. Indek asam amino esensial maisng-masing pakan telah memenuhi jumlah optimal asam amino esensial yang dibutuhkan ikan nila sehingga penambahan tepung Azolla pada pakan layak digunakan.

Penurunan daya cerna protein ini disebabkan kemampuan ikan mencerna protein pakan hanya sampai pada batas tertentu. Ada banyak hal yang mempengaruhinya, salah satu diantaranya adalah kandungan serat kasar pada bahan pakan tersebut. Pada perlakuan P0 memberikan nilai daya cerna protein sebesar $77,50 \%$ dengan serat kasar $4,53 \%$, perlakuan P1 memberikan nilai daya cerna protein sebesar $67,68 \%$ dengan serat kasar 7,5\%, perlakuan P2 memberikan nilai daya cerna protein sebesar $62,19 \%$ dengan serat kasar 6,65\%, dan perlakuan P3 memberikan nilai daya cerna protein sebesar $55,51 \%$ dengan serat kasar 13,58\%. Dari keempat perlakuan 
didapatkan hasil bahwa pada perlakuan P3 yang mengandung serat kasar tertinggi sebesar 13,58\% dengan tingginya kandungan serat kasar ini pakan akan sulit dicerna oleh ikan sehingga pertumbuhan ikan juga akan lambat. Menurut Handajani (2007), bahwa penggunaan kadar serat kasar lebih dari 10\% tidak diperlukan pada pakan ikan-ikan Tilapia dan juga penggunaan serat kasar yang tinggi dalam pakan dapat menurunkan pertumbuhan sebagai akibat dari berkurangnya waktu pengosongan usus dan daya cerna pakan.

Daya cerna protein erat kaitannya dengan komposisi pakan terutama kandungan protein yang ada dalam pakan yang diberikan pada ikan, sebab protein merupakan unsur utama yang dibutuhkan oleh ikan untuk pertumbuhan. Dalam penelitian ini digunakan pakan buatan yang kandungan proteinnya sudah berada dalam kisaran yang dibutuhkan oleh ikan nila GIFT yaitu $\pm 25 \%$. Seperti yang telah dikemukakan oleh Handajani dan Widodo (2010), bahwa pada umumnya ikan membutuhkan pakan yang kandungan proteinnya $20-25 \%$. Kebutuhan protein berbeda pada setiap spesies ikan, dimana pada ikan kornivora kebutuhan protein lebih tinggi bila dibandingkan dengan ikan herbivora.

Dari hasil analisis sidik ragam diperoleh sidik ragam seperti terlihat pada Tabel 4 , sidik ragam tersebut menunjukkan bahwa perlakuan memberikan pengaruh tidak berbeda nyata terhadap daya cerna protein pad aikan nila GIFT (Oreochiomis sp.). Hasil analisis sidik ragam menunjukkan bahwa perlakuan memberikan pengaruh nyata terhadap daya cerna protein ikan nila GIFT (Oreochiomis sp.). Dilihat dari kandungan serat kasar pada 3 perlakuan (P0, P1, P2) menunjukkan kurang dari 10 persen, karena lebih dari 10 persen akan menyebabkan pertumbuhan menurun terhadap ikan-ikan Tilapia. Pada perlakuan P0 dengan kandungan serat kasar terendah $(4,53 \%)$ memberikan daya cerna yang tertinggi $(77,50 \%)$ sedangkan perlakuan P3 dengan kandungan serat kasar tertinggi $(13,58 \%)$ memberikan daya cerna yang terendah $(55,51 \%)$.

\section{SIMPULAN}

Substitusi tepung Azolla terfermentasi sebesar 15\% pada pakan ikan dapat meningkatkan produktivitas ikan Nila dengan hasil pertumbuhan mutlak sebesar 0,81 gram, rasio konversi pakan 3,14 dan daya cerna protein sebesar $67,68 \%$. Penggunaan substitusi tepung Azolla terfermentasi 15\% dalam pakan ikan dapat menekan biaya produksi sebesar $15 \%$ jika dibandingkan penggunaan tepung kedelai tanpa substitusi.

\section{DAFTAR PUSTAKA}

Ahmad, M.A. and Tawwab, M. 2010. The Use of Caraway Seed Meal as a Feed Additive in Fish Diets: Growth Performance, Feed Utilization, and Whole-body Composition of Nile Tilapia, Oreochromis Niloticus (L.) fingerlings. J. Aquaculture, Vol 314, Issue 1-4, Pages 110-114.

Effendie, M.I., 1997. Biologi Perikanan. Penerbit Yayasan Pustaka Nusantara. Yogyakarta. 163 hal.

Haetami dan Sastrawibawa, 2005. Evaluasi Kecernaan Tepung Azolla dalam Ransum Ikan Bawal Air Tawar (Colossoma macropomum). Jurnal Bionatura, Vol. 7, No. 3, November 2005: 225-233.

Handajani, 2000. Peningkatan Kadar Protein Tanaman Azolla Microphylla dengan Mikrosimbion Anabaena Azollae dalam Berbagai Konsentrasi N dan P yang Berbeda pada Media Tumbuh. Tesis. Program Pascasarjana IPB. Bogor.

Handajani, 2006. Pemanfaatan Tepung Azolla Sebagai Penyusun Pakan Ikan terhadap Pertumbuhan dan Daya Cerna Ikan Nila Gift (Oreochiomis sp). Jurnal Penelitian Gamma Vol. 1 No. 2.

Handajani, 2007. Peningkatan Nilai Nutrisi Tepung Azolla Melalui Fermentasi. Laporan Penelitian. Lembaga Penelitian UMM. Malang.

Handajani, 2007. Pengaruh pemberian Bekatul Terfermentasi dengan Rhizophus sp sebagai Penyusun Pakan Ikan terhadap Daya Cerna dan Pertumbuhan Ikan Nila Gift. Prosiding Seminar Nasional Hasil Penelitian Perikanan dan Kelautan UGM (ISBN: 978-979-99781-2-7).

Handajani dan Widodo, 2010. Nutrisi Ikan. UMM Press. Malang.

Hariati, A.M., 1989. Makanan Ikan. LUW/UNIBRAW/Fish Fisheries Project Malang. 99 hal.

Lumpkin, T.A and Plucknet, D.L., 1982. Azolla a green manure: Use abd Management in Crop Production. Westview Tropical Agriculture Series

Tillman, Hariartadi, D., Soedomo, R., Soeharto, P. dan Soekamto, D., 1984. Ilmu Makanan Ternak Dasar. Universitas Gajah Mada. 422 hal.

Uktolseja, J.L.A., 2008. Deposisi Nutrisi Ikan Lele Dumbo (Clarias gariepinus, Burchell) Sebagai akibat Penambahan L-Karnitin Pada Dua taraf Lisin dan Lemak. Jurnal Penelitian Perikanan, Vol. 11, No. 2. Hal: 150-155.

Zonneveld, N.E.A.H dan Boon, J.H., 1991. Prinsip-prinsip Budaya Ikan. Gramedia Pustaka Utama. Jakarta. 318 hal. 